\title{
The Experience and Meaning of Media to Non-Mainstream Athletes: Qualitative Study
}

\author{
Eunhye Yoo ${ }^{1} \mathbb{( D}$, Jeong-Hui Park ${ }^{2} \mathbb{D}$ and Jung-Min Lee ${ }^{2, * \mathbb{C}}$ \\ 1 Department of Physical Education, Seoul National University, 1 Gwanakro, Gwanakgu, Seoul 08826, Korea; \\ yeh04@snu.ac.kr \\ 2 Department of Physical Education, Global Campus, Kyung Hee University, 1732 Deokyoungdaero, \\ Giheung-gu, Yongin-si 17014, Gyeonggi-do, Korea; jeonghee@khu.ac.kr \\ * Correspondence: jungminlee@khu.ac.kr; Tel.: +82-31-201-2736
}

check for

updates

Citation: Yoo, E.; Park, J.-H.; Lee, J.-M. The Experience and Meaning of Media to Non-Mainstream Athletes: Qualitative Study. Sustainability 2021, 13, 1154. https://doi.org/10.3390/ su13031154

Academic Editor: Stefan Bratosin

Received: 16 December 2020

Accepted: 20 January 2021

Published: 22 January 2021

Publisher's Note: MDPI stays neutral with regard to jurisdictional claims in published maps and institutional affiliations.

Copyright: (c) 2021 by the authors. Licensee MDPI, Basel, Switzerland This article is an open access article distributed under the terms and conditions of the Creative Commons Attribution (CC BY) license (https:// creativecommons.org/licenses/by/ $4.0 /)$.

\begin{abstract}
This study aims to understand the process by which ssireum (traditional Korean wrestling), which was labeled a declining industry, has regained its popularity owing to the impact of the media. The study was conducted as a case study with ten ssireum athletes who participated in the television program "The Rhapsody of Ssireum." Additionally, text analysis was performed based on in-depth interviews and auxiliary data collection. As a result, four media-driven transformative trends in ssireum were observed: a shift of the public's interest from online to offline under the influence of media, shift in the public's perception of ssireum athletes' body, birth of ssireum stars with nicknames matching the characteristics of popular ssireum athletes, and ssireum athletes' increased sense of responsibility toward ssireum matches felt under the spotlight of the media. Admittedly, media exposure of ssireum athletes has increased significantly compared to the past. However, for the popularization of ssireum, a sport unique to Korea, the athletes, and the ssireum association need to make a sustained effort.
\end{abstract}

Keywords: ssireum; media exposure; media dependency theory; ssireum athletes; experience; meaning

\section{Introduction}

People are exposed to the media at almost every moment in our daily lives. Not only are people talking about mass media communications (i.e., broadcasting, publishing, and the Internet), but people are also forming relationships with people and getting information through media. Furthermore, individuals in modern society have participated in mediadriven social relations, and the media is interactively connected with society [1]. Living in the 21st century, with the rate of civilization's growth continuing to accelerate, people are tremendously influenced by media [2,3]. In fact, it is no exaggeration to say that we can no longer be free from the unique impact of media; we have passed the point of no return now that we use media to share information in a flash and create a cultural superhighway. Therefore, media changes and developments directly lead to changes in our life experiences [4]. More specifically, media maximizes visual, auditory affects and influences people's interactive environments and real-world experiences [5]. This interaction accelerated the development of the media. For example, while information was obtained from newspapers and radio media in the past, people are using media platforms such as television, social media, and the Internet as more people rely on faster and more convenient information today [6].

Based on this phenomenon, many scholars have developed a theory that media users have become increasingly dependent on media to keep pace with the changing social environment. Media systems are also influenced by media messages to a great extent of their dependence on media, the resultant perceptual, emotional, behavioral changes, and media in a feedback loop $[5,7]$. In this process, if the information on a social phenomenon is delivered rapidly and accurately to media users, the users can respond to an uncertain 
social phenomenon appropriately and backed up by media information. On the contrary, media failure to provide accurate information to its users can lead to media interruption [8].

Dependency on media has a great impact on the sports field as well. From the perspective of media users, they were passive receivers of information due to the limited availability of specialized media resources. However, with the advent of various media platforms (television and social media platforms, internet sources, etc.) due to the development of science and technology, sports have allowed changing the evolutional trajectory of media and the media landscape in general. Media have been put into combining media and sports to attract the public's attention to sports [9]. It functions based on the identification and symbolic effectiveness of values and norms systems that are equally governed by sports and society. Additionally, sports will prove highly suited for extended delivery, as culturally specific behavioral patterns (in the context of social value structures) appear particularly transparent. Media reduces complexity to do more than others in the prescribed framework of various sports rules, promotes communication through the public and media, and makes sport a central source of 'life motivation' and social satisfaction [10]. Due to media sport (sports-related knowledge or information delivered to media users) can induce media users' interest in sports by providing them with vivacity, excitement, and expectation in addition to sports-related information. Kennedy and Hills [10] explained that media sport transcends time and space to reduce people's material and social distance, but it is also a tool providing people with information and experiences. In a similar vein, Shekhawat and Kansal [11] reported that media sport could help people temporarily escape a state of psychological tension and emotional anxiety by delivering sports-related content using information tailored to their concrete need for entertainment. In other words, media sport is currently providing images and narratives limitedly to some handpicked popular disciplines [12].

In particular, disciplines competed in mega sports events (i.e., the Olympic Games, Asian Games, World Cup) have received short-lived attention. For example, owing to the XXIII Olympic Winter Games (i.e., PyeongChang 2018) hosted by South Korea, various winter sports disciplines attracted huge media attention: bobsled, luge, skiing, and snowboarding, let alone the short track speed skating, Korea's best bet for gold medals. This also triggered extensive research activities even on unpopular disciplines, not to mention popular ones $[13,14]$. However, it is challenging for sports neither popular nor competed in a mega sports event to get the public's attention because sports-related interests are associated with social and cultural impact or opportunities to make certain competing disciplines known to the public through specific sports events. Specifically, unpopular sports (field hockey, rugby, handball, ssireum, etc.) in Korea are out of this range of media attention in Korea, such as field hockey, rugby, handball, ssireum, etc.

Among these non-mainstream sports, this study focuses on ssireum, a sport unique to Korea. Ssireum was defined by the Korea ssireum association as followed [15,16]. Ssireum was an intimate game played during a holiday or any festive event, and martial art cultivated basic physical strength in Korea. Over time, it was also used to express the wish to restore national independence during foreign rule. Ssireum is a Korean style wresting in which two competitors wearing satba ( $7 \mathrm{~m}$ long fabric belt) wraps around the waist and thigh. Before the competition, each contestant sits kneeling on the sand ground and starts the game by grabbing onto the opponent's waist and thigh satba using both hands, typically left hand grabbing the opponent's waist satba and right-hand grabbing opponent's thigh satba. The athletes then get up while grabbing each other's satba. The competition will be won if the opponent has touched the ground with a body part above the knee to the ground. In general, the ssireum competition consists of a tournament. The game rules are based on a best-of-three win; however, the best-of-five wins are played in the final. It may sound simple because the competitor wins the game when the opponent's body part from the knees up touches the ground. However, it requires all the more caution and attention and psychological warfare, and a series of complicated techniques and weight imbalance, leading to defeat $[15,16]$. Figure 1 is the basic posture of ssireum athletes when they play. 


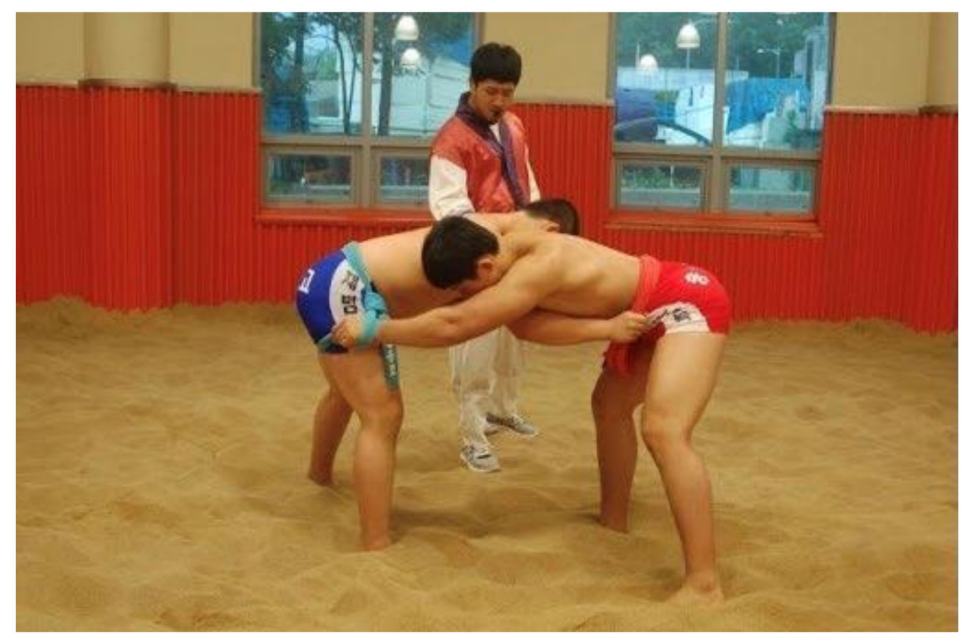

Figure 1. Form of ssireum competition, Source: Korea Ssireum Association.

Throughout history, the form of modern ssireum as a professional sport was established in April 1982 with the Folk Ssireum Committee [15]. Thus launched, ssireum had a heyday from the late 1980s to the mid/late 1990s. There were eight professional ssireum teams, and more than 100 professional athletes were active. These ssireum teams waged fierce scout competition for good athletes. The popularity of ssireum led to an increase in the price of broadcasting contracts and ssireum-related fundraising boom, and ssireum enjoyed a golden age internally and externally not only as Korea's traditional sport but also as a sport appealing to the public [17]. However, in the Asian Financial Crisis outbreak that threw the country into recession and the International Monetary Fund (IMF), Korean society's fatal economic crisis in 1997. The IMF crisis has caused Korea's economic level to fall back to a 10-year level and has led to the nation's economic subordination to developed countries [18]. Furthermore, this has resulted in many crises in economic changes in Korean society and the overall relationships of individuals, families, and social communities. Specifically, in families' case, the economic function centered on families, shown by the existing Korean society, was lost or reduced [19]. Also, changes in family relationships have led to family breakdowns, such as increased divorce rates, abandonment of children and elderly parents, and running away from home. Next, the concept of a lifetime job, which had been prevalent in Korean society, has changed in the workplace. In other words, the existing hierarchical relationship was changed to the contractual relationship between performance and the work-oriented salary system [20]. Finally, the leading cause of the change in social community relationships was unemployment problems. After the IMF crisis, each company was forced to restructure, and mass unemployment was inevitable [21]. Thus, this has had a significant impact on social relationships, not on unemployment itself, putting them on the verge of social inequality and social disintegration.

Due to this crisis, ssireum teams were disbanded as the companies underwent bankruptcy and restructuring one by one, resulting in a dwindling of interest in ssireum. Moreover, although the domain of professional sports was rapidly changing around that time, with various sports going professional, the efforts of associations or federations to respond to the abrupt change were not supportive enough. It is also difficult to expect any revenue because ssireum's range of competition is limited to national leagues and not a discipline of any mega sporting event. Accordingly, most professional ssireum teams operated for corporate promotion landed atop the list of liquidation targets. The consequent decline in corporate sponsorship naturally led to a decline in its popularity as a martial art discipline. Ssireum teams are practically non-existent, and the Korea Ssireum Association is the only organization that keeps ssireum alive. To summarize, the ssireum association's efforts and federation could not efficiently support the teams in responding to the rapidly changing professional sports environment, which resulted in a gradual waning of people's interest in ssireum [22]. 
What distinguishes ssireum from other martial arts, such as wrestling and judo, is that those techniques engage little harm or injury to the opponent. Unfortunately, ssireum is not a discipline admitted to the Olympics and Asian Games, so it is difficult to get people's attention [23]. Its earlier glory completely faded away, and the only spectators in the stadium are their families and friends of athletes. This dire situation makes it even harder to get sponsors and gain public attention. However, ssireum's social and cultural perception as a Korean folk sport cannot be underestimated. In our history, the role of ssireum as people's self-defense skills and as a concrete pillar of the Korean national spirit [22]. With this in mind, the significance of ssireum needs to be evoked to encourage today's Koreans to gain a correct understanding of ssireum and inherit it as an important part of Korean culture.

The use of the media can be the most efficient means to raise people's interest in ssireum. Media lends itself well to delivering the interesting aspects of ssireum such as excitement, thrill, and pleasure. Goettler and Shachar [24] found that the media affected the flow and condition of the public. In addition, research by Kinjo and Ebina [25] reported that ratings and reputations of television programs affect the public's view. Tainsky et al. [26] mentioned that watching television sports games is chosen based on taste and interest. In this context, a Korean television broadcaster aired a reality show titled "The Rhapsody of Ssireum" in November 2019 with the aim of kindling the public's interest in ssireum by showing ssireum's interesting elements such as thrill, joy, excitement, and changing management of the game as survival tournament. The program was a great success. According to Nielsen Korea, a renowned Korean ratings company, "The Rhapsody of Ssireum" ranked third among sports-related entertainment programs [27]. Such use of the media caused a positive change in ssireum as well. In early 2019, one fan posted a YouTube video, which attracted public attention reigniting public interest in ssireum (The number of views on YouTube surpassed 3.5 million views as of November 2020). Thus, the embers of ssireum seemed to revive. However, as the embers were about to fan the flames, COVID-19 emerged, and most matches organized by the ssireum association were canceled or postponed. Since then, efforts have been made to keep the public's interest in ssireum alive via social media.

As such, the Korea Ssireum Association and the public are forced to rely more on the media. Through this, the purpose of this study was to interview in-depth the experiences of ssireum athletes who participated in "The Rhapsody of Ssireum" aired by local broadcasters and to find out the socio-cultural implications of their media exposure. However, TV shows focused on only male ssireum athletes. Therefore, it is still relatively difficult for female ssireum athletes to gain public attention. This part is unfortunate, but it is expected that interest in female ssireum athletes will be expected as interest in ssireum itself increases due to the revival of ssireum. Furthermore, this study scrutinized from a macro-level what kind of efforts were needed to popularize ssireum from a sustainable perspective.

\section{Theoretical Background}

\subsection{Ssireum}

Today, that ssireum results from a transient response that does not aim to preserve traditionalism such as Japan's 'sumo' and Mongolia's 'bökh'. From the perspective of rapid globalization, Koreans who frequently contact foreign cultures should not miss their own identity. Korean traditional culture should be further systematized and inherited to achieve a superior culture. The traditional culture implies the historical nature, identity, and emotion of Korea. As long as Koreans express their roots, people could recognize that they should be preserved, inherited, and developed. This phenomenon can be explained under nationalism. Schiller, et al. [28] stated that ethnicity remains a deep-rooted force in everyday life experiences. In particular, Bairner [29] explained that there is no more intense and widespread nationalistic semantic formation or reinforcement process than sports compared to social behavior and practice (e.g., music, movies, paintings, etc.). For this reason, sports are analyzed as a social system that continuously captures and preserves 
ethnicity, national identity, and nationalism. Therefore, it is common for researchers in various fields to preserve, inherit and develop traditional cultures.

Since ssireum is also a traditional representative culture of Korea, the preservation, propagation, and development of ssireum is justified in preserving and spreading traditional culture. Still, many traditional cultures, including ssireum, must be protected and inherited in modern society [22]. However, in the case of ssireum, there was a lack of research for the preservation and succession of ssireum.

Despite ssireum's unique position as Korea's deep-rooted traditional sport, only a limited number of studies have been dedicated to ssireum. Firstly, the main focus of ssireumrelated studies was on its cultural/anthropological and historical aspects [22,30]. These studies focused on the fact that ssireum is a martial art with humanistic significance. It explained the history of ssireum, which grew with the Korean history, including the Ancient, Goryeo, Chosun, Modern, and Post-liberation of ssireum. Anthropometric studies of ssireum athletes were also conducted [31,32]. Noh, et al. [31] described 25 elite ssireum athletes' muscle conditions, such as isokinetic muscles. Ssireum athletes' isometric dynamometers were used to measure body composition and peak torque at angular speeds at $60^{\circ} / \mathrm{s}$, suggesting that it could be used as a reference for scientific research on physical performance. Other studies also examined ssireum's significance at the community and society levels $[33,34]$. Hur and Kim [35] explained the social and cultural values of ssireum in personality formation, promotion of common sense, cultural transition, cultural exchange, social mobility, close relations with life, proper leisure, economic value, nonviolence, generational gap, and cultural diversity. Among them, it was said that the elements related to national sentiment could inspire community consciousness and listen to the national spirit.

However, limited studies have examined the relationship between ssireum and media. As a study touching on this area, Gong [36] examined the effects of a ssireum match broadcast on immersion in the match and the viewing style. However, to the best of our knowledge, there was a lack of research to delve into ssireum's sociocultural meaning in the light of ssireum athletes' media exposure. Therefore, the purpose of this present study was to conduct an in-depth interview to understand the experiences of the ssireum athletes that participated in "The Rhapsody of Ssireum" aired by a Korean national broadcaster, and to address the social and cultural implications of their media exposure. The second aim of the study was to identify what types of endeavor should be made to popularize ssireum from a more macroscopic and sustainable perspective.

On the other hand, Kong [37] found out that ssireum athletes were suffering significant losses in reaching individual goals, hampered by training-related adverse conditions including peer relationships, mental weakness, and lack of sleep. Kim and Lee [38] also argued that positive motivation for ssireum athletes could lower the dropout rate in the middle of the sport, and that motivation like this also has a positive effect on the athletic attitude. Other studies explored student-ssireum athletes' self-management and exercise programs [39]. There was also a study on self-care and exercise programs of ssireum studentathletes [40]. In addition, related research showed that the experience of middle school ssireum athletes had a positive effect on building awareness, body control, and identity development [41]. Another study was conducted on the isokinetic muscle strength of athletes recovering from physical therapy [31]. Foreign researchers' interest in ssireum was limited. Especially Christopher Sparks [33] was the outstanding foreign researcher interested in exploring Ssireum. He investigated the collective meaning of playing ssireum for community development in Korea. Also, he noted that ssireum is a vehicle for upholding the boundary of national identity with its symbolic and ritual content and thus enacted the identity of ssireum [33].

As examined in previous studies, most ssireum-related studies indicated to individual limitations, comparison with other sports, national identity, and personal development, and little research has been dedicated to ssireum's association with a social structure such as the media. For ssireum to exist as a national traditional culture and sport, continuous research is required to strengthen the traditional and cultural values of ssireum and recognize the 
importance of preservation and succession of traditional Korean culture to the younger generation. To this end, ssireum should provide a foundation for a Korean folk sport and can be an excellent medium for conveying ancestors' identity and spirit to future generations. It also has the task of enhancing ethnicity and maintaining traditionalism through the emotional aspects of ssireum. Therefore, this study is significant in that it finds out the relationship between media and ssireum and paves the way for the revival of ssireum.

\subsection{Media Sport and Media System Dependency Theory}

Media sport is a process by which a small number of people quickly deliver sports to a large number of people through the media. Not only does this narrow their physical, temporal, and social distances, but it is a vehicle to make people taste a wealth of excitement and pleasure by providing a wide variety of contents and aesthetic experiences about sports [42]. Media sport provides subscribers with direct and indirect motivations to participate in sports and helps them temporarily escape psychological tension and emotional unrest by concretizing the essence of sports through sports-related information [43]. Thus, media is a concept emergent from a merge of media and sports as a process of indirectly delivering messages to the public by conveying sports-related knowledge and information or by broadcasting games [44]. Conclusively, without media, sports would have remained only fragmentary events between athletes and the audiences and sports events would have not brought about the social impact or economic effect [10]. Therefore, considering that the function of sports can be expanded and become influential only in tandem with the media, understanding the values of and attitudes toward sports and the relationships formed by participation in sports through media sport may a meaningful task in constructing a paradigm related to sports users' attitude formation and the popularization of sports.

This phenomenon can be explained by the media system dependency theory proposed by Ball-Rokeach and DeFleur [5] according to which the interrelations of media, audience, and society need to be considered to properly understand the media effects on a media user on the microlevel (i.e., individual level). The macro-level is about structural dependencies between the audience, the mass media, and other social systems. The media dependency theory suggested that people rely more on the media to cope with uncertainties and social crises, such as natural disasters. At the micro-level, on the other hand, it depends on the information resources managed by social and media organizations to achieve individual goals and needs. Thus, media dependency theory suggests that certain factors can increase individual dependence on the media and consequently urge that message effects be improved, including the availability of social context factors such as alternative information sources and threats.

In other words, this theory takes into account the role of the media directly involved in the process of maintaining, changing, and bringing the conflict to society as an information system as well as persuading the members of society as an economic system $[45,46]$. The media system dependency theory highlights the importance of media use by equating media use with dependency on the media in satisfying the needs to understand others, act properly in social situations, and to escape from such situations. Ho, Liao, and Rosenthal [47] argued that people rely on the media to get information on specific events and incidents. This is directly associated with using media as a means to perceive threats from the surroundings, thus confirming the dependency on the media as a source of information [48]. Kim and Jung [49] demonstrated that people's dependence on specific media decreases when alternative media exist and that the more people are dependent on the media that provide current political information, people have more biased view [50]. Thus, demonstrating that the absence of alternative media makes people even more dependent on specific media. Collectively, the current study intends to identify how media effects influence ssireum athletes and what forms of direct and indirect effects media can have on the revival of ssireum. 


\section{Methods}

A qualitative study was judged appropriate for an in-depth study on the experiences of the athletes who participated in the program "The Rhapsody of Ssireum" aired by the Korean Broadcasting System (KBS). These athletes presented their experiences in the program, and a case study was conducted accordingly. A case study's design consists of exploring a case (bounded system) over time, collecting data through various information resources including in-depth interviews, along with media materials, and reporting those results in the form of case description and case-based themes [51]. A case study deals with a single case or multiple cases [52]. A single case study examined athlete's behavior that includes complexity and specificity in a particular situation and a multiple case study is conducted through a variety of case applications and complexities to derive feasibility and reliability of the study [53]. Each of the ssireum athletes that participated in "The Rhapsody of Ssireum" were selected as a single case in this study.

\subsection{Participants}

In general, ssireum is divided into four weight classes. The lightweight class includes Taebaek $(-80 \mathrm{~kg})$ and Geumgang $(-90 \mathrm{~kg})$, while the heavyweight class includes Halla $(105 \mathrm{~kg})$ and Baekdu (140 kg). However, before 'The Rhapsody of Ssireum', most of the media showed heavyweight athletes. Therefore, for the general popularization of ssireum, the program was organized around athletes (lightweight) who were relatively unpopular.

Snowball-sampling [54] was implemented to select the participants from the target population of the professional ssireum athletes who participated in the KBS program "The Rhapsody of Ssireum". Before the interview, the study's purpose was clearly explained to the participants, and the researcher obtained oral and written consent by telephone and e-mail. In the process of selecting the participants, the willingness to participate was the most important criterion, so participants who showed discomfort or passive attitude was discontinued. Furthermore, in order to forestall the slightest possibility of involuntary participation, each participant was repeatedly asked about his intention to participate. After the exclusion of the athletes who were hesitant to give interviews from the list of participants, ten athletes were finally selected as participants (Table 1).

Table 1. Characteristics of Participants.

\begin{tabular}{|c|c|c|c|c|c|c|c|}
\hline Name & Age & Weight Class & Hight $(\mathrm{cm})$ & Weight $*(k g)$ & Athlete's Career & Social Media Usage Status & BMI $\left(\mathrm{kg} \cdot \mathrm{m}^{-2}\right)$ \\
\hline A & 31 & Geumgang & 181 & 90 & 19 & Y & 27.47 \\
\hline B & 32 & Geumgang & 183 & 93 & 21 & $\mathrm{Y}$ & 27.77 \\
\hline C & 23 & Geumgang & 182 & 92 & 12 & $\mathrm{~N}$ & 27.77 \\
\hline D & 36 & Geumgang & 186 & 90 & 23 & Y & 26.01 \\
\hline E & 26 & Taebaek & 176 & 83 & 15 & Y & 26.79 \\
\hline $\mathrm{F}$ & 24 & Taebaek & 175 & 80 & 13 & Y & 26.12 \\
\hline G & 28 & Taebaek & 180 & 82 & 13 & Y & 25.31 \\
\hline $\mathrm{H}$ & 27 & Taebaek & 178 & 80 & 16 & Y & 25.52 \\
\hline I & 30 & Taebaek & 182 & 80 & 18 & Y & 24.15 \\
\hline $\mathrm{J}$ & 25 & Taebaek & 179 & 82 & 11 & $\mathrm{~N}$ & 25.59 \\
\hline
\end{tabular}

* Light weight Standards: Taebaek ( $-80 \mathrm{~kg})$, Geumgang (-90 kg).

The participants were six Taebaek $(-80 \mathrm{~kg})$ and four Geumgang $(-90 \mathrm{~kg})$ weight class athletes who kept the rank of third place or higher in national tournaments and had garnered third place or higher at the university league.

\subsection{Data Collection}

After the selection of participants from the pool of ssireum athletes who participated in "The Rhapsody of Ssireum", face-to-face in-depth interviews were conducted with each participant in a quiet room for a deeper understanding of their experience and significance of media exposure. A detailed explanation of the study's purpose was given by phone and email, while the consent was confirmed to participants before the face-to-face interview. In this study, all interviews on smartphones and study participants were stored in folders with 
code (A-J) to ensure anonymity. Each in-depth interview was designed as a hybrid form of semi-structured and unstructured interviews. The interviews were scheduled twice per participant and each lasting time about 40-50 $\mathrm{min}$ long. The questions in the interview were prepared before the interviews based on the in-depth interview checklist [55], adjusting the questions to the participant's replies. An in-depth interview proceeded from general to detailed questions: What do you think media means to ssireum athletes? Do you think media exposure of ssireum has changed the public interest? What efforts are being made to maintain interest in ssireum other than broadcasting? After the scheduled in-depth interview, if the content is insufficient or requires additional information, then necessary information was obtained by conducting additional interviews through email or phone.

\subsection{Data Analysis}

This study was conducted by content analysis for neutrality and systematicity of data analysis. Content analysis is a research method that reveals content patterns and topics through a systematic classification process, coding, based on a holistic understanding of a given data [56,57]. This is also not merely a quantitative way to create categories by grouping similar meanings or counting the number of words, but rather a way to grasp both the internal and external implications of categories by coding the content [58].

Based on contents analysis this study to exclude participants' characteristics and prejudices, the current study used in each in-depth interview was included in the analysis to maintain a neutral perspective, and participants were selected according to systematicity. Data analysis was conducted as follows: First, each study participant was organized into separate units (participant A, B, C, etc.). Moreover, the researcher tried to analyze each participant independently without overlap. So this stage, the researcher converted the audio file from in-depth interviews into individual participant's files. In this process, the participants were temporarily divided into subcategories, and the files were organized into the respective folders by date and time. Then, the researcher wanted to link the interpretation differences in unit data to the differences in independent observations and contextual interpretations. Data obtained from interviews with each study participant were classified by topic. After that, researchers recorded this phenomenon and compared it with the researcher's analysis without time constraints. The researcher repeatedly read the indepth interview data, categorizing and encoding each participant's transcripts as proposed by Spradley [59]. The meanings of the contents representing conspicuous phenomena were captured and conceptualized. This process aimed to derive the qualitative data implications by bringing the participants' experiences of media exposure into context with the sociocultural significance they face. The researcher tried to explain the study results in the description so that others could understand them. Description means that others realize the practical importance of their results and are used for other studies. Thus, this step sought to relate the meaning and experience of ssireum athletes' media exposure to the results.

\subsection{Trustworthiness and Ethic of Study}

Qualitative study is focused on the meaning of relationships, which participants can use to understand and derive the meaning of vivid experiences. However, securing neutrality is crucially essential when conducting research. Therefore, the process of describing and reflecting the researcher's thoughts on the participant before proceeding with this study, as suggested by Steinke [60], prevented subjectivity and preconception from intervening in the research process. Ensuring the trustworthiness of analysis data was reviewed using various techniques including multiple verifications, peer scrutiny, and member checks of data proposed by Lincoln and Guba [61]. Additionally, the researcher endeavored to ensure reliability and credibility by exercising continuous self-scrutiny based on the checklist of essential questions proposed by Hollway and Jefferson [62]: What did the researcher pay attention to? How can we interpret the researcher's attention? How can we be sure that the 
researcher's interpretations are correct? To ensure the ethics of this study, voluntary consent was sought from the participants after sufficiently explaining the purpose of this study.

The participants were informed of the possibility of withdrawal in case they may feel any discomfort during the study or suspect any disadvantages through the participation in the study. Lastly, for privacy and personal information protection of the study participants, all data generated during the study were kept confidential and all the names were given one-letter codes.

\section{Result and Discussion}

This study analyzed the experience and meaning of the media exposure of ssireum, a non-mainstream sport event. Through this, it was not only to find out the current status of the event called ssireum, but also to understand what efforts were needed to revive ssireum. The results showed that (1) From Online to Offline: The Sand Pit to be Reignited, (2) Rediscovery of ssireum athletes: Physique reinterpreted by the media, (3) Birth of Stars: from "Ssireum-Dol" to "Emperor", and (4) Driving Force: Increased Sense of Responsibility for the Game.

\subsection{From Online to Offline: The Sand Pit to Be Reignited}

Ssireum enjoyed its heyday in the 1980s. It had been thrust into the spotlight as a national sport and its popularity lasted decades with mega-class ssireum stars. Entering the new millennium, however, it suffered a downturn in the wake of a national crisis. All attempts at its revival and South and North Korea's joint inscription onto the UNESCO list of intangible cultural assets on 26 November 2018, were not enough to regain its former glory. In recent years, it has increasingly attracted public attention. Interest in ssireum was rekindled by the use of social media (four million YouTube views), not through television channels. This interest has expanded to popularity in offline settings. The traditional media has embarked on ssireum-related reality shows. The Korea Ssireum Association, which had been yearning for the popularization of ssireum, and the athletes, was able to capture public attention through the "The Rhapsody of Ssireum" program, which brought the public to the stadium. As if to prove its popularity, "The Rhapsody of Ssireum" final round was sold out within $10 \mathrm{~min}$ of the ticket lines opening.

"Right. Before The Rhapsody of Ssireum, only people who related ssireum athletes came to the stadium. After the program was aired, different groups of fans are coming." (Participant C)

"In the first live broadcast, I saw a scene that I had never seen since I was born. When I saw the crowd that filled the stadium, I got goosebumps (...). In our 'the Rhapsody of Ssireum' final, 6000 seats were sold out in a matter of a few minutes." (Participant A)

As you can see from the two participants' interviews above, many people gathered to watch "The Rhapsody of Ssireum". The show played the role of a steppingstone for ssireum revival through the media effect of disseminating the charm of Korean folk sport ssireum, which was about to fall into oblivion, with a program seeking public benefits. In particular, the proclaimed purpose of promoting an "unpopular" sport was persuasive to the public, which led them to watch the program, and they could be more immersed in the program. One of the participants remembered the audience who filled the stadium for "New Year's Ssireum Tournament" and said he felt the offline popularity for the first time. As if to prove such popularity, many of the ssireum athletes appeared in various television shows and even commercials (health food, sportswear, etc.).

"To be honest, you know, before start this program the popularity of ssireum has plummeted compared to the past. The Rhapsody of Ssireum made many people realize that ssireum is not a dull sport at all. (...) Nowadays, people recognize us when we are in ssireum uniform... I enjoy it that ssireum is again popular." (Participant J) 
"I really couldn't imagine that much. As you know, X and other athletes are now busy. They make appearances in entertainment programs and take pictures for photo albums. I think this was really a good opportunity to promote ssireum." (Participant $\mathrm{H}$ )

As shown above, athletes received unexpected attention from the public after they appeared on the television show. They see therein an opportunity to revive ssireum and frankly express their hope. Like Rowe [42] study this suggests that online popularity can be expanded to offline popularity. This was a phenomenon derived from a video posted online. The fans that came to the offline venue (i.e., live shooting location) could directly obtain information on the athletes. The athletes were positively aware of the popularity gained through the unexpected public interest after the show. They regarded this phenomenon as an opportunity to announce the revival of ssireum. Ssireum was again within the interest range of the public. The live television show allowed ssireum to regain the glory of the 1980s.

In general, media dependency suggests that the higher a person's media dependency regarding specific information, the higher the message effect provided by the media [5]. Furthermore, the media usually recognizes rare phenomena or dramatic happenings as news stories and selectively highlights these topics to amplify public interest [42]. In other words, ssireum, which kindled the viewers' interest online, received the spotlight of the media and aroused public interest in ssireum (popularization of ssireum along the trajectory of social media to legacy media). The use of different media platforms has increased opportunities to arouse public interest in ssireum. The athletes were also aware that driven by such media effects, ssireum athletes became popular guests of television shows and were enjoying popularity on social media, which in turn made the popularity of ssireum soar even more.

\subsection{Rediscovery of Ssireum Athletes: Physique Reinterpreted by the Media}

The predominantly perceived adjectives for ssireum athletes had been, until recently, strong, sturdy, and clumsy [17]. This is a stereotype formed among the public about ssireum athletes ascribable to the fact that the media used to show only heavyweight athletes (Halla: up to $100 \mathrm{~kg}$; Baekdu: up to $140 \mathrm{~kg}$ ). Also, the media constantly showed only the heaviest weight class among ssireum athletes. Therefore, people had little opportunity to see lightweight athletes (Taebaek: up to $80 \mathrm{~kg}$; Geumgang: up to $90 \mathrm{~kg}$ ). Aware of this stereotype, "The Rhapsody of Ssireum" arranged a tournament with lightweight athletes, considered marginal among the ssireum athletes, and aired live the entire tournament until the birth of the Taegeuk Master. This was an occasion for the public to change their perception of ssireum and ssireum athletes. The ssireum athletes interviewed were enthusiastic about this change.

"People began to change their ideas about ssireum to see lightweight athletes on 'The Rhapsody of Ssireum'. They used to think that all ssireum athletes are tall and heavy. Now I sometimes hear that the lower-grade ssireum is more interesting, and people recognize me wherever I go. I enjoy hearing 'Ssireum athletes have a nice physique'. I think people's perception of ssireum has changed a lot." (Participant G)

"In the past, people did not even know that there are small ssireum athletes. Presently, many people recognize me as a ssireum athlete, and they find it no longer strange that small men athelet ssireum." (Participant E)

The participants said that their appearance on the television show brought about a shift in stereotype perception of ssireum and that they feel the change directly from the reactions they get from the public. Athletes who feel firsthand such reactions were willing to appear on the television show, when given the opportunity, to inform the public that there are four different weight classes because ssireum is dynamic and not less interesting than other popular sports. They were sure that media power affects strongly in terms of making such positive aspects of ssireum known to the public. What is noteworthy is that weight classes occupied the highest portion of the above in-depth interviews. From 
this, the study could confirm that they were marginalized in the past for belonging to the lightweight classes and that their appearance on "The Rhapsody of Ssireum" flipped the public attention to the lightweight ssireum athletes.

Not only in the perception of public-for physique; but also their general perception of ssireum underwent a radical shift. The image of ssireum athletes in the minds of the general public was predominantly struggling in difficult conditions. The athletes stressed that ssireum athletes are paid commensurate to their performance and ranking like the athletes of any other sports. Figure 2 showed the spectacular skills of the athletes in the 'The Rhapsody of Ssireum'.

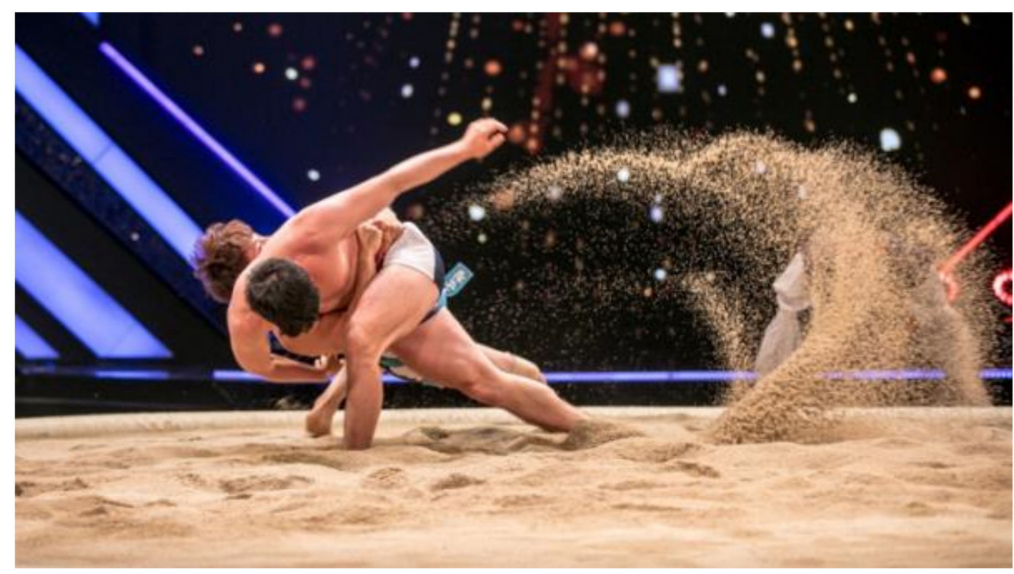

Figure 2. Technique of Ssireum, Source: KBS 2TV 'The Rhapsody of Ssireum'.

"When I say I do ssireum, they wonder how I can sustain my livelihood... The fact is that the annual pay I get from the City Hall I belong to is at the level of any big company. People do not seem to be familiar with this fact." (Participant F)

"They used to tell me why I was insisting on a sport that makes no money. Now they ask what I am doing with all the money I earn (laughter). They even look at me with different eyes." (Participant B)

The athletes who experienced firsthand the media power are willing to participate in television show programs. They witnesses the positive results of the combined impact of media and sport in attracting public attention when the interest in that sport was declining [46]. The Rhapsody of Ssireum kindled and fueled the interest in ssireum by delivering live matches with additional sparkles of vivacity and thrill in addition to information on the athletes [63]. This narrowed the distance between ssireum and the public and instilled in people's minds that ssireum is not the monopoly of tall, heavy athletes, but a great ssireum game with dozens of strategies and techniques would showcase some of the most inspirational ssireum athletes.

Conclusively, media contributed to the shift of general perception that ssireum is not a dull sport only for adult audiences, but an interesting and attractive sport for all populations. The athletes interviewed were aware of the role of media in dissipating the stereotype image of ssireum and ssireum athletes.

\subsection{Birth of Stars: From "Ssireum-Dol" to "Emperor"}

There are many reasons for the public's paying attention to the media. There may be various reasons, but at the present moment where sports have become a part of popular culture, stars are at the heart of the media [64]. Ssireum is also not an exception. When ssireum was in a deep slump, not only the bodies that were hardened by satba fight, but also the attractive appearance of the athletes were posted on YouTube, which triggered a phenomenon of giving them catchy nicknames among fans, and broadcasters amplified this phenomenon. As a result, ssireum stars were born. The athletes selected for the TV 
show have an excellent physique and good-looking faces that could attract the public's attention and have excelled in skills, heightening public interest.

"I was dazed. I wonder why I was so famous all of a sudden... It was even embarrassing. I could not make heads or tails of it. All the same, I enjoyed it very much that my fans filled the stadium and cheered me up." (Participant D)

"When I first heard my nickname announced, I was quite embarrassed and ill at ease. But the more I heard it, the more I liked it. It was interesting and I was even very grateful. They created my unique image." (Participant I)

As shown in the above in-depth interview, the athletes were ill at ease in the unfamiliar environment, but they ended up feeling grateful for the attention they were receiving. As mentioned by participant I, they positively accepted the frame standing for their techniques and appearances.

"A good nickname? It's good... it gives you an image. Like entertainment celebrities, they call us by cute nicknames, too. This means they pay attention to us... We are getting more popular, right?" (Participant F)

"Eh... Me too. I do love to be in the center of attention. I found it interesting that people showed interest in me during the live show. I try to live up to my nickname, posting good things on social media. I am keen to show my good sides, how I exercise for good matches, and the like." (Participant A)

Participants also made personal efforts to maintain the frames created by the television show and to improve. For example, one of them personally managed his appearance and continuously made efforts to train himself not only for the show but also through personal social media.

The television show created a character that fits each athletes' characteristics, which boosted their popularity. For example, when the satba of athletes got torn apart, he got the nickname "Man with the Torn Satba" (in Korean acronym, something like "Satoman"), and an athlete famous for his speedy play got "3-Sec-Winner" as a nickname. An athlete with a sculpture-like appearance was nicknamed "David in the Sand Pit." There was also "Emperor" who got that nickname for an incredible number of final victories. In a similar vein, Sanderson [65] explained that the media promotes content through sports stars and increases the number of viewers by using their specific images. There may be differences in the image of stars depending on the sports-related broadcasting character, which suggests that the higher the use of media sport, the stronger the public perceives its news frames and media effects [64]. This is in line with the finding that the birth of a sports star is generally determined by the power of the media. In other words, the media can exert a decisive influence on the formation of the image and social significance of ssireum athletes (i.e., the actors of sports) based on the intrinsic meaning or the symbolism and importance of their sports activities. For this reason, the television show was making its portion of contribution to increasing the popularity of ssireum based on the athletes' skills as well as their images, with all the athletes shining like entertainment stars. Such an opportunity can be interpreted as a result of putting spotlights on their specific images in the media.

Conclusively, the media was creating sports stars around their specific images putting them at the center stage of sociocultural influence, which also had an influence on the athletes' self-promotion and activities reaching far beyond the public attention.

\subsection{Driving Force: Increased Sense of Responsibility for the Game}

Sports stars are athletes who have gained idol-like images in the minds of the public [65]. Sports stars are persons who exercise influence on the public through the images formed by the media, with their exertion expanding in the sports industry and even the cultural industry. Their influences are positions beyond the scope of impact they offer to the public through their personal experiences because the epithet of "star" puts them in the public sphere [44]. Consequently, the responsibility imposed on them is also enormous. 
The athletes given the epithet of the star had a glim sense of responsibility associated with their stardom. In particular, athletes of unpopular sports such as ssireum valued their popularity very highly. With the surge of interest in ssireum they experienced for the first time through the television show, they were feeling the responsibility. They also expressed their wish to further disseminate ssireum through the media while not neglecting training.

"That was also the reason why I participated in The Rhapsody of Ssireum. I wanted to promote ssireum and contribute to its growth. These days, I am the most frequent attendee together with $X$ and $Y$. When the invitation comes along, we accept it, saying we need to do it. Our fans say the same thing. Now that there are no tournaments, we have to appear on the show all the more frequently. Z also started a YouTube channel for the same reason." (Participant E)

"I' $m$ still an active ssireum athlete, but I wish to participate in the show as long as it does not interfere with my training. As a matter of fact, I want to advance in ssireum and its promotion. The show and training are interdependent. No ssireum, no show. No show, no promotion of ssireum. So, I wanna do both." (Participant I)

They also felt their responsibilities in maintaining ssireum's popularity and expressed their intention to do their best so that the current attention would not be short-lived.

"Just to think that many people are looking at me reminds me of my responsibility. I will have to do my best in training to show good and elegant matches. The people will show more interest in ssireum." (Participant $\mathrm{H}$ )

"Had it not been for COVID-19, more fans would have come to ssireum, I think. It was pure bad luck. I learned about it in January in the X open chatting room. I go to the chatting to communicate room from time to time. I forward news about ssireum tournaments and my daily life. Of course, I use social media. it is like a minimum etiquette to people who show interest in me..." (Participant B)

From the above in-depth interviews, it can be inferred that ssireum athletes were using chat rooms and social media (i.e., Facebook, Instagram) to communicate with fans and keep up their interest in ssireum. Media exposure was of course important to arouse their interest in ssireum and ssireum athletes, but they also felt the need to make personal efforts to keep it up. The athletes tried to communicate with the public beyond time and space by visiting the platforms they use and explain that they share information about the tournament schedules, and venues (if "untact" [Korean equivalent for non-face-to-face] matches, on what channels). There were exposing themselves on social media to promote communication with the public or spread a pro-social atmosphere [65]. The athletes think that the interest in ssireum was regained solely and using social media as a mechanism to reinforce the confidence of the public while solidifying the foothold of ssireum. Ssireum in the past was on the decline, and today the media has aroused public interest through 'the rhapsody of Ssireum.' Only selected athletes appeared in the program, and the ssireum athletes thought they represented the ssireum athletes' image. Therefore, they believed that athletes were responsible for making efforts in various fields, such as appearance, physical ability, and internal character, for maintaining public interest.

\section{Conclusions}

The purpose of the present study is to investigate the effects of media exposure of ssireum athletes on the public interest in ssireum. To this end, 10 ssireum athletes who participated in the live reality program "The Rhapsody of Ssireum" aired by the Korean Broadcasting System (KBS) participated in the in-depth interviews, and all data were analyzed by content analysis. The conclusions read as below:

(1) Ssireum athletes were expecting that their media exposure would contribute to the revival of ssireum. Its start was modest compared with other sports, but communication on social media attracted the attention of the public and the soaring public interest led to a live reality television show "The Rhapsody of Ssireum." This boosted the public interest in 
ssireum and brought people to the ssireum arena (i.e., sand pit). The characteristic of the media is that it accepts rare phenomena or dramatic events as news, and it amplifies public interest by selectively highlighting special topics [42]. This trend of the media can shine even more when combined with the public interest and new information related to it [44]. In the same vein, the media put a spotlight on the ssireum athletes who went viral online and ignited the public interest in ssireum.

(2) Media effects made the rediscovery of ssireum athletes possible. The typical image of tall and heavy ssireum athletes formed by the media in the past was reinterpreted, and the public learned that ssireum was not a monopoly of heavy-bodied athletes, but there were also agile ssireum athletes with well-developed muscular physiques. Furthermore, the public's perception of ssireum was changing from a dull sport with simple techniques to an attractive sport requiring enormous muscle power, a wealth of agile techniques, and refined strategies.

(3) Birth of stars is an important element in the promotion of ssireum. In any sport, stars should be at its heart to attract public attention [43]. The ssireum athletes interviewed in this study explained how they were given nicknames for the creation of characters matching their characteristics. Nicknaming did contribute to creating stars and skyrocketing them to fame and fortune, i.e., the media can exert a decisive influence on the formation of the image and social significance of ssireum athletes (i.e., the actors of sports) based on the intrinsic meaning or the symbolism and importance of their sports activities. Based on the images created by the media added to their performance, the television show contributed to sending most ssireum athletes to stardom stealing the scene of young music celebrities (called idols in Korea) and boosting ssireum's popularity [36]. A great fragment of this success is attributable to the media effect of highlighting a specific image of each of these ssireum athletes.

(4) Ssireum athletes' increased sense of responsibility felt under the spotlight of the media may also be considered media effects. They received unprecedented attention from the public through the television show. Aware of that, they felt their responsibility to keep up the popularity of ssireum. They highly valued this rare opportunity to contribute to popularizing ssireum and they were keen to assume their full responsibility. For this reason, they were acting with a public self-awareness $[44,64]$ to keep up their fans' attention alongside self-management as ssireum athletes. For example, they tried to communicate with fans on social media. Of course, they considered it important to have gained public interest through their media exposure, but they considered it just as important to keep endeavoring to keep their fans' attention.

As examined above, ssireum has recently regained popularity thanks to support from the media. However, external as well as personal efforts are needed to maintain this interest continuously. For example, ssireum athletes need try to communicate with the public by using social media personally to promote ssireum. In addition, ssireum associations need to make efforts to use the media to promote ssireum's appeal to the public. Based on this conclusion, the strength of this study is to find how the media influenced ssireum, an unpopular sport in Korea. In addition, little has been studied about ssireum, which makes it even more important than the public knows more about this sport. Many Research is being conducted in Korea on physical fitness, BMI, psychological improvement, and athletic ability measurements of ssireum athletes. Of course, the mental and physical aspects of the players are also important. However, at a time when interest in ssireum is fading, there has been little research on ways or related policies to improve it. Due to these limitations were found and suggestions were made in this study.

Although today's society is dependent on the media, the media attention is focused on some athletes and weight classes, which can lead to inequality of interest. Of course, the increasing interest in ssireum revolving around these athletes is a positive phenomenon for the popularization of ssireum. However, it is also necessary to put the media spotlight evenly (equally) on various types of athletes. In other words, research needs to be conducted 
also on heavyweight athletes (Halla and Baekdu classes) and the athletes marginalized by the media.

Next, strategies need to be set up to keep up the interest of associations and sponsors by cleverly using the positive media effects in addition to promoting the personal development of ssireum athletes. At the same time, the media should redouble internal and external efforts toward ssireum's Renaissance by instilling in the public at the earlier glory of ssireum, which had its heyday in the 1980s. A follow-up study needs to be conducted to examine how (from which perspectives) these efforts unfold.

Finally, when this study was conducted, the ssireum athletes who benefited from the media were male ssireum athletes. It was difficult to find female ssireum athletes who experienced media exposure. Most previous studies also deal with only male athletes although female ssireum athletes do exist. This gender inequality should be addressed because female athletes are also part of the ssireum landscape. Research is required to find out the status of female ssireum athletes in terms of competitions, sponsorship of the association, and influence of the media.

Author Contributions: Data curation, E.Y., J.-H.P. and J.-M.L.; Formal analysis, J.-H.P. and J.-M.L.; Investigation, E.Y.; Methodology, E.Y., J.-H.P. and J.-M.L.; Project administration, J.-M.L.; Writingoriginal draft, E.Y.; Writing—review \& editing, E.Y. and J.-M.L. All authors have read and agreed to the published version of the manuscript.

Funding: This research received no external funding.

Institutional Review Board Statement: The study was conducted according to the guidelines of the Declaration of Helsinki, and approved by the Institutional Review Board (or Ethics Committee) of Seoul National University (protocol code: IRB No. 1904/003-004).

Informed Consent Statement: Informed consent was obtained from all subjects involved in the study.

Data Availability Statement: The data are held with the authors.

Acknowledgments: The authors would like to thank all participants who participated in this study.

Conflicts of Interest: The authors no conflict of interest to declare.

\section{References}

1. Raetzsch, C.; Lünenborg, M. Practicing Media-Mediating practice anchoring practices for public connection: Media practice and its challenges for journalism studies. Int. J. Commun. 2020, 14, 2868-2886.

2. Reese, S.D.; Shoemaker, P.J. A media sociology for the networked public sphere: The hierarchy of influences model. Adv. Found. Mass Commun. Theor. 2018, 19, 96-117. [CrossRef]

3. Tiggemann, M.; Hayden, S.; Brown, Z.; Veldhuis, J.J.B. The effect of Instagram "likes" on women's social comparison and body dissatisfaction. Body Image 2018, 26, 90-97. [CrossRef] [PubMed]

4. Thorson, K.; Wells, C. Curated flows: A framework for mapping media exposure in the digital age. Commun. Theory 2016, 26, 309-328. [CrossRef]

5. Ball-Rokeach, S.J.; Defleur, M.L. A dependency model of mass-media effects. Commun. Res. 1976, 3, 3-21. [CrossRef]

6. Sparks, C. Globalization, Development and the Mass Media; Indian Institute of Management: Kozhikode, India, 2007.

7. Lee, K.E.; Kim, S.-H.; Ha, T.-Y.; Yoo, Y.-M.; Han, J.-J.; Jung, J.-H.; Jang, J.-Y. Dependency on smartphone use and its association with anxiety in Korea. Public Health Rep. 2016, 131, 411-419. [CrossRef] [PubMed]

8. Meraz, S. The fight for 'how to think': Traditional media, social networks, and issue interpretation. Journalism 2011, 12, 107-127. [CrossRef]

9. Wheaton, B.; Thorpe, H. Action sport media consumption trends across generations: Exploring the olympic audience and the impact of action sports inclusion. Commun. Sport 2018, 7, 415-445. [CrossRef]

10. Kennedy, E.; Hills, L. Sport, Media and Society; Berg: Oxford, UK, 2009.

11. Shekhawat, M.; Kansal, T. Role of media in promotion of sports. Indian J. Phys. Educ. Sports Med. Exerc. Sci. 2019, 19, 15-18.

12. Knoppers, A.; Elling, A. 'We do not engage in promotional journalism' discursive strategies used by sport journalists to describe the selection process. Int. Rev. Sociol. Sport 2004, 39, 57-73. [CrossRef]

13. Lee, K.Y.; Kim, H.T. A study on the achievements and tasks of the 2018 PyeongChang Winter Olympic Games. J. Korea Entertain. Ind. Assoc. 2018, 12, 151-166.

14. Lee, J.-H.; Kim, T.-H. The effect of sponsorship activity for unpopular sports on the corporate image and purchase intention: Focusing on the winter sports events. Korean J. Sports Sci. 2020, 29, 549-561. [CrossRef] 
15. Korea Ssirem Association. Introduction of Ssireum. Available online: http://ssireum.sports.or.kr/gnb/bbs/content.php?co_id= eng2_01 (accessed on 18 November 2020).

16. Wikipedia Ssireum. Available online: https://en.wikipedia.org/wiki/Ssireum (accessed on 15 November 2020).

17. Kim, K.-T.; Kim, H.-S.; Kang, H.-J.; Hwang, S.-H. Globalization of Ssireum. J. Korea Contents Assoc. 2012, 12, 355-365. [CrossRef]

18. Hwang, K.S. Korean society's changes after imf crisis. Theory Res. Citizsh. Educ. 1999, 52, 355-378.

19. Kim, H.K. Failure of the patrilineal stem family system? Familialism and individualization among the generation of economic crisis of korea in 1998. Korean Sociol. Assoc. 2013, 47, 101-141.

20. Kim, S.-K.; Finch, J. Confucian patriarchy reexamined: Korean families and the imf economic crisis. Good Soc. 2002, 11, 43-49. [CrossRef]

21. Ahn, C.Y. Financial and corporate sector restructuring in south korea: Accomplishments and unfinished agenda. Jpn. Econ. Rev. 2001, 52, 452-470. [CrossRef]

22. Shim, S.-K. The identity and heritage value of Ssireum. Asian Comp. Folk. Soc. 2018, 67, 145-176. [CrossRef]

23. Huh, Y.; Kong, S.; Nam, Y. The structural relationship between collegiate ssireum players' occupational values, decision-making self-efficacy, and career maturity. J. Korean Alliance Martial Arts 2019, 21, 129-140.

24. Goettler, R.L.; Shachar, R. Spatial competition in the network television industry. RAND J. Econ. 2001, 624-656. [CrossRef]

25. Kinjo, K.; Ebina, T. State-dependent choice model for tv programs with externality: Analysis of viewing behavior. J. Med. Econ. 2015, 28, 20-40. [CrossRef]

26. Tainsky, S.; Salaga, S.; Santos, C.A. Determinants of pay-per-view broadcast viewership in sports: The case of the ultimate fighting championship. J. Sport Manag. 2013, 27, 43-58. [CrossRef]

27. NielsonKorea TOP 20 LIST FOR TV PROGRAMS. Available online: https:/ / www.nielsenkorea.co.kr/tv_terrestrial_day.asp? menu=Tit_1\&sub_menu=1_1\&area=01 (accessed on 13 November 2020).

28. Schiller, N.G.; Çaglar, A.; Guldbrandsen, T.C. Beyond the ethnic lens: Locality, globality, and born-again incorporation. Am. Ethnol. 2006, 33, 612-633. [CrossRef]

29. Bairner, A. Sport, nationalism and globalization: Relevance, impact, consequences. Hitotsubashi J. Arts Sci. 2008, $49,43-53$.

30. Kim, H.K. The history of ssireum' (traditional Korean wrestling)—Based on its historical changes. J. Korean Folk. 2003, 37, 5-52.

31. Noh, J.W.; Park, B.S.; Kim, M.Y.; Lee, L.K.; Yang, S.M.; Lee, W.D.; Lee, T.H. Analysis of isokinetic muscle strength for sports physiotherapy research in Korean ssireum athletes. J. Phys. Ther. Sci. 2015, 27, 3223-3226. [CrossRef]

32. Rhi, S.; Lee, J.; Lee, Y.; Kim, K. Changes of body composition, physical fitness, and blood variables according to the short-term weight reduction in college ssireum athletes. J. Exerc. Rehabil. 2019, 15, 74-77. [CrossRef]

33. Sparks, C.A. Wrestling with Ssireum: Korean Folk Game vs. Globalization; Texas A and M University: College Station, TX, USA, 2012.

34. Sparks, C.A. Traditions and Play as ways to develop community. In Culture. Community and Development; Rhonda, P., Mark, A., Tingwuan, L., Eds.; Routeledge: London, UK, 2020; pp. 90-123.

35. Hur, Y.; Kim, H.S. National sentiment of pork ssireum: Focusing on xing (fun and pleasure). Korean Soc. Philos. Sport Danc. Martial Arts 2012, 20, 65-82.

36. Gong, S. The effect of Ssireum relay broadcasting on the viewing flow and viewers' type. J. Korean Alliance Martial Arts 2013, 15, 1-12.

37. Kong, S. The Structural relationship among adolescent ssireum players' passion, self-management and exercise flow. J. Sport Leis. Stud. 2017, 67, 209-219.

38. Kim, B.G.; Lee, T.H. The relationship between ssireum athletes' motivational factors and training dropout and attitude. Korean J. Sports Sci. 2018, 27, 189-198. [CrossRef]

39. Kong, S.; Kwon, J. The relationship between coaches' positive and negative feedback, self-efficacy, and exercise flow. J. Korean Alliance Martial Arts 2018, 20, 43-54. [CrossRef]

40. Cho, B.M.; Lee, K.M.; Lim, S.M. Middle school students' experiences and significance as ssireum players. Korea J. Sport 2019, 17, 785-796.

41. Noh, J.; Kim, J.H.; Kim, J. Somatotype analysis of Korean wrestling athletes compared with non-athletes for sports health sciences. Toxicol. Environ. Health Sci. 2013, 5, 163-168. [CrossRef]

42. Rowe, D. Assessing the sociology of sport: On media and power. Int. Rev. Sociol. Sport 2015, 50, 575-579. [CrossRef]

43. Kabadayi, A. Analysing the types of TV programmes viewed by children from different socio-economic strata based on their self-report in the turkish context. Educ. Med. Int. 2006, 43, 147-164. [CrossRef]

44. Wenner, L.A. Sport and media. In Routledge Handbook of the Sociology of Sport; Giulianotti, E., Ed.; Routledge: New York, NY, USA, 2015; pp. 377-387.

45. Jung, J. Media dependency theory. Int. Encycl. Med. Eff. 2017, 12, 1-10. [CrossRef]

46. Jackob, N. No alternatives? The relationship between perceived media dependency, use of alternative information sources, and general trust in mass media. Int. J. Commun. 2010, 4, 589-606.

47. Ho, S.S.; Liao, Y.; Rosenthal, S. Applying the theory of planned behavior and media dependency theory: Predictors of public pro-environmental behavioral intentions in Singapore. Environ. Commun. 2015, 9, 77-99. [CrossRef]

48. Gavin, N.T. Media definitely do matter: Brexit, immigration, climate change and beyond. Br. J. Politics Int. Relat. 2018, 20, 827-845. [CrossRef]

49. Kim, Y.-C.; Jung, J.-Y. SNS dependency and interpersonal storytelling: An extension of media system dependency theory. New Med. Soc. 2016, 19, 1458-1475. [CrossRef] 
50. Cha, Y.-R. Strategic use of SNS in PR for improving trust in government policy. J. Korea Contents Assoc. 2013, 13, 103-116. [CrossRef]

51. Stake, R.E. The Art of Case Study Research; Sage Publications: Thousand Oaks, CA, USA, 1995.

52. Creswell, J.W.; Poth, C.N. Qualitative Inquiry and Research Design: Choosing Among Five Approaches; Sage Publications: Thousand Oaks, CA, USA, 2016.

53. Yin, R.K. Case Study Research and Applications: Design and Methods; Sage Publications: Thousand Oaks, CA, USA, 2017.

54. Goodman, L.A. Snowball Sampling. Ann. Math. Stat. 1961, 32, 148-170. [CrossRef]

55. Patton, M.Q. Qualitative Research and Evaluation Methods; Sage Publications: Thousand Oaks, CA, USA, 2002.

56. Mayring, P. Qualitative Content Analysis: Theoretical Background and Procedures. In Teaching and Learning Secondary School Mathematics; Kajander, A., Holm, J., Chernoff, E.L., Eds.; Springer: Cham, Switzerland, 2015; pp. 365-380.

57. Mayring, P. Qualitative content analysis. In A Companion to Qualitative Research; Flik, U., von Kardorff, E., Steinke, I., Eds.; Sage Publications: London, UK, 2004; pp. 159-176.

58. Krippendorff, K. Content Analysis: An Introduction to Its Methodology; Sage Publications: Los Angeles, CA, USA, 2018.

59. Sapradley, J.P. Participant Observation; Holt Rinehart and Winston: New York, NY, USA, 1980.

60. Steinke, I. Quality criteria in qualitative research. In A Companion to Qualitative Research; Flick, U., von Kardorff, E., Steinke, I., Eds.; Sage Publications: Thousand Oaks, CA, USA, 2004; pp. 184-190.

61. Lincoln, Y.S.; Guba, E.G. Judging the quality of case study reports. Int. J. Qual. Stud. Educ. 1990, 3, 53-59. [CrossRef]

62. Hollway, W.; Jefferson, T. Doing Qualitative Research Differently: Free Association, Narrative and The Interview Method; Sage Publications: London, UK, 2000.

63. Coakley, J. Sports in Society: Issues and Controversies, 11th ed.; McGraw-Hill Higher Education: London, UK, 2014.

64. Deller, R.A. Star image, celebrity reality television and the fame cycle. Celebr. Stud. 2016, 7, 373-389. [CrossRef]

65. Sanderson, J. It's a Whole New Ball-Game: How Social Media Is Changing Sports; Hampton Press: New York, NY, USA, 2011. 